\title{
Bio-potential application of algae in reducing the toxicity of the fly ash from coal processing: a new trend of reclamation
}

\begin{abstract}
Fresh water algal growth inhibition test with unicellular alga Ankistrodesmus falcatus, Scenedesmus obliquus, Selenastrum capricornutum, and Microcoleus vaginatus is of great interest in biodiversity science. Our investigation has been made in laboratory continuous culture using sterile sewage as the medium for the start-up growth of these species. And since, these are at risk level when meet the coal industry waste, a suitable bioassay application based on an oxidizing medium of arsenic, cadmium, mercury, and selenium was implemented for algal incubation. First, the algistatic-algitidal levels were reported. Second, the observed growth inhibition with the value of IC 50 (the concentration which inhibits algae growth by $50 \%$ ) was invested to obtain the growth responses and to define the range of the studied elemental variations. Noticeably, the median EC50 of the scrubber ash slurry extract (SASE) was 3-15\%. Further, the results showed that the toxicity of the heavy metals depends on their chemical speciation and can be related to their free ion activities and their concentrations.
\end{abstract}

Keywords: toxicity, fly ash, Microcoleus vaginatus, oxidizing medium, EC50, ecosystem
Volume 2 Issue 2 - 2018

Nuha Al Masri

Department of Chemistry, Syrian Private University, Syria

Correspondence: Noha Almasri, Department of Chemistry, Faculty of Medicine, Syrian Private University, Damascus, Syria, Tel +9639334 46993, Email almasrinuhasy@gmail.com

Received: March 06, 2018 | Published: April 20, 2018

\section{Introduction}

Increasing energy demands and the national program emphasizing the use of coal have stimulated mining and on-site combustion of vast deposits in several countries. These activities have posed new environmental considerations in many regions previously undisturbed or even pristine in character. Bituminous and sub-bituminous coals contain a broad spectrum of trace-elements, some of which have toxic properties (e.g. arsenic, cadmium, mercury, and selenium) and have been shown to be considerably enriched in coal relative to average crustal abundance on Earth. ${ }^{1}$ Additional enrichment of the more volatile toxic elements occurs during the combustion process; subsequent condensation takes place on the surface of submicron fly ash particles which escape emission control devices and become biologically available. ${ }^{2}$

Present emission control technology, which can exceed 98\% removal of fly ash particulates, includes electrostatic precipitators and venturi wet scrubbers. Both types of installations are found in the newer, large western coal-fired power plants. ${ }^{3}$ Both electrostatic precipitators and wet venturi scrubber systems used in coal-fired generating plants produce an ash that is also a potential pollutant. Mahlaba et al. ${ }^{4}$ indicated that molybdate, borate, fluoride, selenate, and arsenate were soluble contaminants from coal ash disposed in alkaline environments.

The potential deposition of trace elements from coal-fired generating plants has received increasing attention in recent years due to their adverse effects on the environment. ${ }^{5}$ To minimize the effects of these toxic trace elements, their deposition rates should not reach concentrations which are incompatible with naturally functioning ecosystems. The compatible level for each trace element depends on the interaction of physicochemical and biological components of the ecosystem which directly or indirectly determine the chemical state of the element, its concentration, its availability, ${ }^{6}$ and the potential for bioconcentration in the food web.

The use of algal toxicity tests to monitor the biological impact of pollutants is important because algae are primary producers in aquatic systems. Such tests provide one approach to determining compatible levels of trace elements, although care must be taken to create a test situation which represents as closely as possible the natural situation being examined. Because pollutants from coal-fired generating plants typically enter aquatic ecosystems in small quantities over long periods, ${ }^{6}$ a chronic exposure test is indicated when investigating their potential toxicity.

The objectives of this study were to develop an algal toxicity test system, based on the EPA Algal Assay Procedure Bottle Test, for determining the median effective concentration (EC50) values of heavy metals as potential pollutants from coal-fired power plants. ${ }^{7}$ The EC50 values which have been developed for $\mathrm{As}(\mathrm{V}), \mathrm{Cd}(11), \mathrm{Hg}(\mathrm{II})$, and $\mathrm{Se}(\mathrm{VI})$, in solution, and for extracts of scrubber ash slurry from a western coal-fired generating plant are based on dose--response relationships for algae indigenous to southeastern part of Syria and Selenastrum capricornutum, an EPA test algae.

\section{Materials and methods}

The Algal Assay Procedure Bottle Test (AAPBT) was adapted to evaluate the effect of $\mathrm{As}(\mathrm{V}), \mathrm{Cd}(\mathrm{ll}), \mathrm{Hg}(\mathrm{II})$, and $\mathrm{Se}(\mathrm{VI})$, in solution, and of scrubber ash slurry extract from the Colstrip coal-fired power generating plant on selected algal species. The algae used in these investigations were the freshwater chlorophytes Ankistrodesmus falcatus (CoMa) Ralfs, Scenedesmus obliquus (Turp.) Kutz., and Selenastrum capricornutum Printz, and the freshwater cyanophyte Microcoleus taginatus (Vauch.) Gom. These species subsequently were referred to by their generic names. 
Ankistrodesmus, Scenedesmus, and Microcoleus were isolated from phytoplankton collections from stock ponds in Sweda, Syria. The unialgal, bacteria-free cultures of Ankistrodesmus and Scenedesmus were obtained by repeated streaking of isolated colonies on Petri plates containing 1.5\% Bacto-Agar (Difco) in Algal Assay Medium (AAM) ${ }^{8}$ Stock cultures of Ankistrodesmus and Scenedesmus were maintained in AAM. Microcoleus was isolated using similar streaking techniques but substituting Gorham's nutrient medium ${ }^{9}$ for AAM. Stock cultures of Microcoleus were grown in Gorham's medium because Microcoleus could not be maintained in AAM. The unialgal Microeoleus was not bacteria-free. An axenic culture of Selenastrum was obtained and maintained in AAM. The axenic cultures were checked for bacteria with each transfer using Difco Tryptone Glucose Extract Agar (TGEA).

Laboratory toxicity testing was followed procedures outlined by the Syrian Public Health Association. Polycarbonate flasks and all glassware in contact with trace element solutions or scrubber ash slurry extract were rinsed with $10 \% \mathrm{HNO}_{3}$ solutions. All other glassware was rinsed with recommended $10 \% \mathrm{HCl}$ solutions.

Polycarbonate flasks, rather than glass, were used for toxicity test containers in the trace element toxicity studies. Some investigators have used polycarbonate flasks. ${ }^{10}$ Hai et al. ${ }^{11}$ reported that mercury adsorption on the walls of silicone glass was a serious problem. Lee et al. ${ }^{12}$ found adsorption of cadmium on the walls of Pyrex glass also was a cause for concern. Investigations with ${ }^{76} \mathrm{As}(\mathrm{III}),{ }^{115 \mathrm{~m}} \mathrm{Cd}(\mathrm{II})$, and ${ }^{75} \mathrm{Se}(\mathrm{IV})$ in our laboratory indicated that less than $5 \%$ of the elements were adsorbed on the walls of polycarbonate flasks at $0.01,0.001$ and $0.01 \mathrm{mg} / \mathrm{L}$, respectively.

Similar test conditions were imposed for all toxicity tests. The culture media used for toxicity tests were the same as those used for stock cultures. The chelator (EDTA) was omitted in toxicity tests, although small quantities necessarily were introduced via the algal inocula. The micronutrients also were omitted from AAM. Chemical precipitates remaining in the culture media after autoclaving were dissolved by the addition of $1 \mathrm{~N} \mathrm{HCI}$. The test elements were introduced as analytical reagent grade salts of $\mathrm{Na}_{2} \mathrm{HAsO}_{47} \mathrm{H}_{2} 0, \mathrm{CdSO}_{4}, \mathrm{HgSO}_{4}$, and $\mathrm{Na}_{2} \mathrm{SeO}_{4}$. Stock solutions containing $1 \mathrm{~g} / \mathrm{L}$ element were prepared using deionized water. The stock solutions were acidified with $\mathrm{HCl}$ to $\mathrm{pH}$ 1.5. The appropriate range of test concentrations was obtained by diluting the stock solutions aseptically with sterile culture media. Element levels of 0 (control), 0.01, 0.1, 1, 10 and $100 \mathrm{mg} / \mathrm{L}$ were used in the initial toxicity screenings. Treatment levels of subsequent experiments were dependent on initial results of toxicity screening. The $\mathrm{pH}$ of each test culture solution was adjusted to $7.0 \pm 0.3$ with $\mathrm{NaOH}$ or HCI solution prior to inoculation with the test alga.

The toxicity tests with scrubber ash slurry were conducted using an extract of the scrubber ash slurry obtained from the settling pond for Units 1 and 2 of the coal-fired generating plant. The extract was prepared by filtering the slurry ( $10 \%$ solids) through $0.45 \mu \mathrm{m}$ Millipore filters, mixing the filtrate with the appropriate algal medium, and filter-sterilizing through $0.22 \mu \mathrm{m}$ Millipore filters. The toxicity tests were conducted using percentages of algal medium/slurry extract stock solutions in the appropriate algal medium. The $\mathrm{pH}$ of the test solution varied with the concentration of the slurry extract. The scrubber ash slurry extract (SASE), without nutrients, was analyzed for $\mathrm{pH}$, specific conductance, alkalinity, total phosphate, ammonia nitrogen, nitrate-nitrite nitrogen, total organic carbon, silica, and sulfate. An aliquot also was analyzed for selected trace elements using inductively coupled plasma-atomic emission spectroscopy.

All treatment levels of the trace elements and SASE were tested in triplicate for each experimental run. The experimental runs were repeated for each combination until the dose-response relationship was well-defined. The number of runs ranged from two to five for each experimental combination. Test flasks were inoculated from 10- to 14-day axenic cultures of Ankistrodesmus, Scenedesmus, or Selenastrum to give a final cell concentration of $1 \times 10^{4}$ cells/ $\mathrm{mL} \pm 10 \%$. The Microcoleus inoculum, of the same age, was $1 \mathrm{~mL}$ of a stock culture reading $30 \%$ transmission at $450 \mathrm{~nm}$ on a Hach DREL2 spectrophotometer. All test cultures were incubated in 500$\mathrm{mL}$ polycarbonate flasks containing $100 \mathrm{ml}$ of test culture solution. The cultures were incubated at $24 \pm 2^{\circ} \mathrm{C}$ under $400 \mathrm{ft}-\mathrm{c} \pm 10 \%$ mixed illumination ("cool white" fluorescent and incandescent), measured adjacent to the flask at the liquid level, on a 16:8 h light: dark regime.

After two weeks the algae were harvested and analyzed for chlorophyll a (Trichromatic Method) as outlined by the Syrian Public Health Association. The extracted chlorophyll was read on a modified Gilford spectrophotometer with a 1-cm light path. Percent of control (response) values were calculated using chlorophyll a values. The chlorophyll a detection limit of the algal assay method was approximately the same as the chlorophyll a inoculation level. Therefore, either an algistatic or algicidal response could be indicated by a chlorophyll a value of zero. A t-test was used to determine if the response was significantly different from $100 \%$ of the control. Concentrations of the toxic solutions which produced $50 \%$ of the control responses, i.e. the median effective concentrations (EC50 values), were found by fitting a line to the dose-response relationship by least squares using the $\operatorname{Iog}_{10}$ of the dose as the independent variable.

\section{Results}

The growth responses ( $\%$ of control values) of Ankistrodesmus, Scenedesmus, Selenastrum, and Microcoleus on exposure to $\mathrm{As}(\mathrm{V})$, $\mathrm{Cd}(\mathrm{II}), \mathrm{Hg}(\mathrm{II}), \mathrm{Se}(\mathrm{VI})$, and SASE are presented in Tables 1-5, respectively. Selenastrum is increasingly inhibited with an increasing $\mathrm{As}(\mathrm{V})$ concentration between 10 and $75 \mathrm{mg} / \mathrm{L}$. A similar response was found for Ankistrodesmus and Scenedesmus, from 0.01 to 5 and 0.01 to $50 \mathrm{mg} / \mathrm{L}$, respectively. The first treatment level to cause a statistically significant inhibitory response to Selenastrum was $25 \mathrm{mg} / \mathrm{L}$. The first significant growth inhibition of Ankistrodesmus and Scenedesmus occurred at 0.1 and $0.01 \mathrm{mg} / \mathrm{L} \mathrm{AS(V),} \mathrm{respectively.} \mathrm{Microcoleus} \mathrm{was}$ not significantly inhibited at any treatment level. In fact, a stimulatory response was noted at $75 \mathrm{mg} / \mathrm{L}$. Algistatic-algicidal responses were noted for Ankistrodesmus and Scenedesmus at 5 and $50 \mathrm{mg} / \mathrm{L} \mathrm{As}(\mathrm{V})$, respectively.

Cadmium (II) was extremely inhibitory, causing significant inhibition of Ankistrodesmus, Scenedesmus,

and Microcoleus at $0.01 \mathrm{mg} / \mathrm{L}$ and Selenastrum at $0.05 \mathrm{mg} / \mathrm{L}$ (Table 2). All the algae responded algistatically-algicidally at or below $0.3 \mathrm{mg} / \mathrm{L}$. A significant stimulatory response was noted for Ankistrodesmus with $0.001 \mathrm{mg} / \mathrm{L}$.

The sensitivity of the algal species to $\mathrm{Hg}$ (II) was variable (Table 3). The first significant inhibition of Ankistrodesmus, Scenedesmus, Selenastrum, and Microcoleus occurred at 0.05, 0.1, 0.01 and $0.4 \mathrm{mg} / \mathrm{L} \mathrm{Hg}$ (II), respectively. Algistatic-algicidal responses for Ankistrodesmus, Scenedesmus, and Selenastrum were first noted at $0.4 \mathrm{mg} / \mathrm{L}$. Microcoleus approached an algistatic response at $1.0 \mathrm{mg} / \mathrm{L}$. 
The sensitivity of the algal species to Se (VI) varied (Table 4). The first significant inhibition of Ankistrodesmus, Scenedesmus, Selenastrum, and Microcoleus occurred at 0.01, 0.1, 0.3 and 10 $\mathrm{mg} / \mathrm{L} \mathrm{Se}$ (VI), respectively. Microcoleus was stimulated by treatment levels of $1.0 \mathrm{mg} / \mathrm{L}$ and below. Algistatic-algicidal responses by Ankistrodesmus, Scenedesmus, and Selenastrum appeared at 10, 4 and $1.7 \mathrm{mg} / \mathrm{L}$, respectively. Microcoleus approached an algistatic response at $50 \mathrm{mg} / \mathrm{L}$.

The first significant inhibition of Ankistrodesmus, Scenedesmus, Selenastrum, and Microcoleus occurred at 1, 5, 10 and 5\% SASE, respectively (Table 5). Algistatic-aigicidal responses for Ankistrodesmus, Scenedesmus, and Selenastrum were indicated at 50, 100 and $75 \%$ SASE. Microcoleus approached an algistatic response at $100 \%$ SASE.

The chemical analysis of the SASE is presented in Table 6. The extract was high in sulfate, nitrogen (nitrate-nitrite), total phosphate, silica, calcium, magnesium, manganese, specific conductance and alkalinity. Several potentially toxic trace elements were found to be present at low levels.

The regression models used for predicting EC50 values of As (V), Cd (II), Hg (II), Se (VI), and SASE are presented in Table 7. No regression model is presented for the As (V)-Microcoleus combination because Microcoleus was not significantly inhibited at the highest treatment level. All of the final regression models except $\mathrm{Hg}$ (II)-Scenedesmus and Se(VI)-Scenedesmus have coefficient of determination $\left(\mathrm{R}^{2}\right)$ values above 0.60 (Table 7).

Table I Growth responses of Ankistrodesmus, Scenedesmus, Selenastrum, and Microcoleus to As(V)

\begin{tabular}{lllllllll}
\hline As(V), $\mathbf{m g} / \mathbf{L}$ & \multicolumn{2}{l}{ Ankistrodesmus } & \multicolumn{2}{l}{ Scenedesmus } & \multicolumn{2}{l}{ Selenastrum } & \multicolumn{2}{l}{ Microcoleus } \\
\hline & $\mathrm{n}^{\mathrm{a}}$ & $\mathrm{y} \pm \mathrm{se}^{\mathrm{b}}$ & $\mathrm{n}$ & $\mathrm{y} \pm \mathrm{se}$ & $\mathrm{n}$ & $\mathrm{y} \pm \mathrm{se}$ & $\mathrm{n}$ & $\mathrm{y} \pm \mathrm{se}$ \\
0.01 & 3 & $61 \pm 18$ & 5 & $58 \pm 20^{*}$ & 6 & $78 \pm 26$ & 6 & $106 \pm 23$ \\
0.1 & 3 & $72 \pm 4^{*}$ & 6 & $48 \pm 15^{*}$ & 6 & $87 \pm 30$ & 6 & $97 \pm 13$ \\
1 & 6 & $52 \pm 22^{*}$ & 6 & $26 \pm 10^{*}$ & 6 & $76 \pm 24$ & 6 & $99 \pm 17$ \\
5 & 3 & 0 & - & - & - & - & - & - \\
10 & 6 & 0 & 5 & $4 \pm 5^{*}$ & 5 & $104 \pm 26$ & 6 & $106 \pm 13$ \\
25 & 3 & 0 & 3 & $1 \pm 2^{*}$ & 3 & $50 \pm 18^{*}$ & 3 & $90 \pm 17$ \\
50 & 6 & 0 & 3 & 0 & 3 & $9 \pm 2^{*}$ & 3 & $78 \pm 26$ \\
75 & 6 & 0 & 3 & 0 & 3 & $4 \pm 10^{*}$ & 3 & $115 \pm 4^{*}$ \\
100 & 6 & 0 & 3 & 0 & 6 & $14 \pm 15^{*}$ & 6 & $97 \pm 17$ \\
\hline
\end{tabular}

${ }^{a}$ Number of observations.

${ }^{b}$ Standard error of the mean.

Value significantly different from $100 \%(p<0.05)$.

Table 2 Growth responses of Ankistrodesmus, Scenedesmus, Selenastrum, and Microcoleus to Cd(II)

\begin{tabular}{lllllllll}
\hline $\mathrm{Cd}(\mathrm{II}), \mathrm{mg} / \mathrm{L}$ & Ankistrodesmus & \multicolumn{2}{l}{ Scenedesmus } & \multicolumn{2}{l}{ Selenastrum } & \multicolumn{2}{l}{ Microcoleus } \\
\hline & $\mathrm{n}^{\mathrm{a}}$ & $\mathrm{y} \pm \mathrm{se}^{\mathrm{b}}$ & $\mathrm{n}$ & $\mathrm{y} \pm \mathrm{se}$ & $\mathrm{n}$ & $\mathrm{y} \pm \mathrm{se}$ & $\mathrm{n}$ & $\mathrm{y} \pm \mathrm{se}$ \\
0.001 & 3 & $156 \pm 13^{*}$ & 2 & $118 \pm \mathrm{II}$ & 2 & $89 \pm 73$ & 3 & $118 \pm 23$ \\
0.005 & 3 & $99 \pm 34$ & 3 & $78 \pm 18$ & 3 & $106 \pm 58$ & 3 & $89 \pm 21$ \\
0.01 & 7 & $69 \pm 29^{*}$ & 8 & $8 \pm 12^{*}$ & 6 & $61 \pm 28$ & 6 & $69 \pm 12^{*}$ \\
0.05 & 6 & $8 \pm 5^{*}$ & 6 & 0 & 6 & $17 \pm 7^{*}$ & 6 & $3 \pm 3^{*}$ \\
0.1 & 9 & $1 \pm I^{*}$ & 9 & 0 & 8 & $7 \pm 5^{*}$ & 6 & $1 \pm I^{*}$ \\
0.2 & 3 & 0 & 3 & 0 & 3 & $2 \pm I^{*}$ & - & - \\
0.3 & 6 & 0 & 6 & 0 & 6 & 0 & 3 & 0 \\
\hline
\end{tabular}

aNumber of observations.

bStandard error of the mean.

"Value significantly different from $100 \%(p<0.05)$.

The EC50 values for the test algae exposed to the trace elements and SASE are presented in Table 8. The EC50 values ranged from 0,048-30.761 mg/L (0.00064-0.41058 M) As (V), 0.005-0.019mg/L (0.00004-0.00017 M) Cd(11), 0.033-0.253mg/L (0.00016--0.00126
M) $\mathrm{Hg}$ (II), $0.033-8.511 \mathrm{mg} / \mathrm{L}(0.00042-0.10779 \mathrm{M}) \mathrm{Se}(\mathrm{VI})$, and $3.048-15.417 \%$ SASE. The test algae with the lowest EC50 values were Scenedesmus for As (V) and Cd (II), Selenastrum for $\mathrm{Hg}(\mathrm{II})$, Ankistrodesmus for Se(VI), and Microcoleus for SASE. 
Table 3 Growth responses of Ankistrodesmus, Scenedesmus, Selenastrum, and Microcoleus to Hg(II)

\begin{tabular}{lllllllll}
\hline $\mathbf{H g}(\mathrm{II}), \mathbf{m g} / \mathbf{L}$ & \multicolumn{2}{l}{ Ankistrodesmus } & \multicolumn{2}{l}{ Scenedesmus } & \multicolumn{2}{l}{ Selenastrum } & \multicolumn{2}{l}{ Microcoleus } \\
\hline & $\mathrm{n}^{\mathrm{a}}$ & $\mathrm{y} \pm \mathrm{se}^{\mathrm{b}}$ & $\mathrm{n}$ & $\mathrm{y} \pm \mathrm{se}$ & $\mathrm{n}$ & $\mathrm{y} \pm \mathrm{se}$ & $\mathrm{n}$ & $\mathrm{y} \pm \mathrm{se}$ \\
0.001 & 3 & $91 \pm 28$ & 6 & $150 \pm 78$ & 3 & $99 \pm 12$ & - & - \\
0.01 & 5 & $92 \pm 14$ & 9 & $86 \pm 19$ & 6 & $88 \pm 1 I^{*}$ & 6 & $99 \pm 10$ \\
0.05 & 3 & $70 \pm 1 I^{*}$ & 5 & $86 \pm 39$ & 3 & $52 \pm 2 \mathrm{I}$ & 5 & $79 \pm 40$ \\
0.1 & 8 & $48 \pm 32^{*}$ & 8 & $55 \pm 46^{*}$ & 6 & $6 \pm 10^{*}$ & 6 & $102 \pm 12$ \\
0.4 & 3 & 0 & 6 & 0 & 3 & 0 & 5 & $42 \pm 22^{*}$ \\
0.7 & 3 & 0 & 6 & 0 & 3 & 0 & 5 & $12 \pm 16^{*}$ \\
$\mathrm{I}$ & 9 & 0 & 9 & 0 & 9 & 0 & 5 & $1 \pm 2^{*}$ \\
\hline
\end{tabular}

aNumber of observations.

'standard error of the mean.

"Value significantly different from 100\% ( $p<0.05)$

Table 4 Growth responses of Ankistrodesmus, Scenedesmus, Selenastrum, and Microcoleus to Se(IV)

\begin{tabular}{|c|c|c|c|c|c|c|c|c|}
\hline \multirow[t]{2}{*}{$\mathrm{Se}(\mathrm{IV}), \mathrm{mg} / \mathrm{L}$} & \multicolumn{2}{|c|}{ Ankistrodesmus } & \multicolumn{2}{|c|}{ Scenedesmus } & \multicolumn{2}{|c|}{ Selenastrum } & \multicolumn{2}{|c|}{ Microcoleus } \\
\hline & $\mathrm{n}^{\mathrm{a}}$ & $y \pm s e^{b}$ & $\mathrm{n}$ & $y \pm s e$ & $\mathrm{n}$ & $y \pm s e$ & $\mathrm{n}$ & $y \pm s e$ \\
\hline 0.01 & 7 & $70 \pm 31 *$ & 3 & $236 \pm 129$ & 3 & $89 \pm 8$ & 3 & $118 \pm I^{*}$ \\
\hline 0.05 & 3 & $46 \pm I^{*}$ & 6 & $152 \pm 70$ & - & - & 3 & $105 \pm 12$ \\
\hline 0.1 & 9 & $30 \pm 14 *$ & 15 & $48 \pm 32^{*}$ & 8 & $84 \pm 19$ & 3 & $116 \pm 9$ \\
\hline 0.2 & 3 & $19 \pm 2 *$ & 3 & $58 \pm 15^{*}$ & 3 & $81 \pm 19$ & - & - \\
\hline 0.3 & 3 & $18 \pm 3 *$ & 3 & $2 I \pm 5^{*}$ & 3 & $48 \pm 17^{*}$ & - & - \\
\hline 0.4 & 3 & $10 \pm 4 *$ & 8 & $19 \pm 10 *$ & 6 & $20 \pm 14^{*}$ & 3 & $128 \pm 6 *$ \\
\hline 0.5 & 3 & $13 \pm 3^{*}$ & - & - & 3 & $32 \pm 11 *$ & - & - \\
\hline 0.6 & 3 & $10 \pm 2^{*}$ & - & - & 2 & $33 \pm 5 *$ & - & - \\
\hline 0.7 & 3 & $9 \pm 2 *$ & 7 & $18 \pm 8^{*}$ & 6 & $16 \pm 8^{*}$ & 3 & $117 \pm 7^{*}$ \\
\hline 0.8 & 2 & $12 \pm 2^{*}$ & - & - & 3 & $15 \pm I^{*}$ & - & - \\
\hline 0.9 & 3 & $11 \pm 3^{*}$ & - & - & 3 & $18 \pm 5^{*}$ & - & - \\
\hline 1 & 8 & $10 \pm 10 *$ & 12 & $12 \pm 8^{*}$ & 9 & $5 \pm 6 *$ & 6 & $110 \pm 3^{*}$ \\
\hline 1.4 & 3 & $12 \pm 0 *$ & 2 & $\mathrm{II} \pm 4^{*}$ & 3 & $2 \pm 3 *$ & - & - \\
\hline 1.7 & 3 & $7 \pm I^{*}$ & 3 & $8 \pm 3 *$ & 3 & 0 & - & - \\
\hline 2 & 3 & $8 \pm 3 *$ & 2 & $8 \pm 8 *$ & 3 & 0 & - & - \\
\hline 4 & - & - & 6 & 0 & - & - & - & - \\
\hline 5 & - & - & - & - & - & - & 3 & $73 \pm 11$ \\
\hline 10 & 3 & 0 & - & - & 3 & 0 & 3 & $50 \pm 6 *$ \\
\hline 20 & - & - & - & - & - & - & 2 & $16 \pm 4 *$ \\
\hline 30 & - & - & - & - & - & - & 3 & $6 \pm 2 *$ \\
\hline 40 & - & - & - & - & - & - & 3 & $4 \pm 3 *$ \\
\hline 50 & - & - & - & - & - & - & 3 & $5 \pm 2 *$ \\
\hline
\end{tabular}

aNumber of observations.

bStandard error of the mean.

"Value significantly different from $100 \%(p<0.05)$ 
Table 5 Growth responses of Ankistrodesmus, Scenedesmus, Selenastrum, and Microcoleus to scrubber ash slurry extract (SASE).

\begin{tabular}{lllllllll}
\hline SASE & \multicolumn{2}{l}{ Ankistrodesmus } & \multicolumn{2}{l}{ Scenedesmus } & \multicolumn{2}{l}{ Selenastrum } & \multicolumn{2}{l}{ Microcoleus } \\
\hline & $\mathrm{n}^{\mathrm{a}}$ & $\mathrm{y} \pm \mathrm{se}^{\mathrm{b}}$ & $\mathrm{n}$ & $\mathrm{y} \pm \mathrm{se}$ & $\mathrm{n}$ & $\mathrm{y} \pm \mathrm{se}$ & $\mathrm{n}$ & $\mathrm{y} \pm \mathrm{se}$ \\
$0.0 \mathrm{I}$ & 6 & $98 \pm 32$ & 5 & $103 \pm 26$ & 4 & $98 \pm 42$ & 5 & $106 \pm 15$ \\
0.1 & 6 & $72 \pm 42$ & 5 & $72 \pm 26$ & 6 & $88 \pm 31$ & 5 & $103 \pm 6$ \\
$\mathrm{I}$ & 6 & $72 \pm 18^{*}$ & 5 & $115 \pm 6 \mathrm{I}$ & 4 & $135 \pm 66$ & 6 & $98 \pm 15$ \\
5 & 6 & $57 \pm 17^{*}$ & 5 & $65 \pm 9 *$ & 6 & $98 \pm 42$ & 5 & $19 \pm 4^{*}$ \\
10 & 6 & $61 \pm 15^{*}$ & 5 & $62 \pm 17^{*}$ & 6 & $61 \pm 20^{*}$ & 6 & $8 \pm 3^{*}$ \\
25 & 6 & $4 \pm 3^{*}$ & 6 & $5 \pm 3^{*}$ & 6 & $40 \pm 10^{*}$ & 6 & $7 \pm \mathrm{I}^{*}$ \\
50 & 5 & 0 & 6 & $1 \pm \mathrm{I}^{*}$ & 6 & $2 \pm 3^{*}$ & 6 & $4 \pm 4^{*}$ \\
75 & 6 & 0 & 6 & $2 \pm 2^{*}$ & 6 & 0 & 6 & $1 \pm 2 *$ \\
100 & 6 & 0 & 6 & 0 & 6 & 0 & 6 & $\mathrm{I} \pm \mathrm{I}^{*}$ \\
\hline
\end{tabular}

${ }^{a}$ Number of observations.

bStandard error of the mean.

"Value significantly different from 100\% $(p<0.05)$

Table 6 Chemical analysis of scrubber ash slurry extract (SASE)

\begin{tabular}{|c|c|c|c|}
\hline Parameter & Concentration $^{a}$ & Parameter & Concentration $^{\mathrm{a}}$ \\
\hline $\mathrm{pH}$ & 7.3 & $\mathrm{Ba}$ & 0.04 \\
\hline Specific conductance & 9750 & $\mathrm{Be}$ & 0 \\
\hline Alkalinity ${ }^{\mathrm{b}}$ & 248 & $\mathrm{Ca}$ & 360 \\
\hline $\mathrm{SO}_{4}^{2-}$ & 10.2 & $\mathrm{Cd}$ & 0.04 \\
\hline C-total organic & I & Co & 0.32 \\
\hline $\mathrm{NH}_{3}-\mathrm{N}$ & 0.4 & $\mathrm{Cu}$ & 0 \\
\hline $\mathrm{NO}_{2}^{-}+\mathrm{NO}_{2}^{--\mathrm{N}}$ & 21.4 & $\mathrm{Fe}$ & 0.07 \\
\hline $\mathrm{PO}_{4}^{3-}$-total & 1.6 & $\mathrm{Mg}$ & $>100$ \\
\hline $\mathrm{Si}$ & 91 & $M n$ & 47 \\
\hline $\mathrm{Al}$ & 0.56 & $\mathrm{Ni}$ & 0.3 \\
\hline As & 0.25 & $\mathrm{Zn}$ & 0.12 \\
\hline
\end{tabular}

${ }^{\mathrm{a}} \mu \mathrm{mhos} \mathrm{cml}$ - for specific conductance and $\mathrm{mg} / \mathrm{L}$ for all other parameters except $\mathrm{pH}$.

${ }^{\mathrm{b}} \mathrm{pH} 4.5$ as $\mathrm{CaCO}_{3}$.

Table 7 Regression equations of algal responses to selected trace element or SASE treatment levels

\begin{tabular}{llll}
\hline $\begin{array}{l}\text { Test } \\
\text { substance }\end{array}$ & Alga & Regression equation & $\mathbf{R}^{2}$ \\
\hline \multirow{2}{*}{ As } & Ankistrodesmus & $\mathrm{Y}=-26.963\left(\log _{10} \chi\right)^{\mathrm{a}}+34.053$ & 0.64 \\
& Scenedesmus & $\mathrm{Y}=-18.700\left(\log _{10} \chi\right)+25.25 \mathrm{I}$ & 0.7 \\
& Selenastrum & $\mathrm{Y}=-96.029\left(\log _{10} \chi\right)+192,868$ & 0.79 \\
& Ankistrodesmus & $\mathrm{Y}=-78.401\left(\log _{10} \chi\right)-84.306$ & 0.89 \\
$\mathrm{Cd}$ & Scenedesmus & $\mathrm{Y}=-115.248\left(\log _{10} \chi\right)-215.247$ & 0.82 \\
& Selenastrum & $\mathrm{Y}=-65.792\left(\log _{10} \chi\right)-63.788$ & 0.64 \\
& Microcoleus & $\mathrm{Y}=-65.747\left(\log _{10} \chi\right)-70.207$ & 0.91 \\
$\mathrm{Hg}$ & Ankistrodesmus & $\mathrm{Y}=-54.274\left(\log _{10} \chi\right)-10.201$ & 0.63 \\
& Scenedesmus & $\mathrm{Y}=-50.592\left(\log _{10} \chi\right)-4.257$ & 0.46 \\
& Selenastrum & $\mathrm{Y}=-78.388\left(\log _{10} \chi\right)-66.496$ & 0.86 \\
& Microcoleus & $\mathrm{Y}=-72.355\left(\log _{10} \chi\right)+6.822$ & 0.67 \\
\hline
\end{tabular}


Table Continued..

\begin{tabular}{llll}
\hline $\begin{array}{l}\text { Test } \\
\text { substance }\end{array}$ & Alga & Regression equation & $\mathbf{R}^{2}$ \\
\hline \multirow{3}{*}{ Se } & Ankistrodesmus & $Y=-30.462\left(\log _{10} \chi\right)+4.754$ & 0.69 \\
& Scenedesmus & $Y=-73.596\left(\log _{10} \chi\right)+10.8 I I$ & 0.53 \\
& Selenastrum & $Y=-79.893\left(\log _{10} \chi\right)+5.465$ & 0.8 \\
& Microcoleus & $Y=-66.669\left(\log _{10} \chi\right)+\mid 12.036$ & 0.96 \\
& Ankistrodesmus & $Y=-92.339\left(\log _{10} \chi\right)+|47.3| 4$ & 0.79 \\
& Scenedesmus & $Y=-70.753\left(\log _{10} \chi\right)+\mid 16.941$ & $0.7 \mid$ \\
& Selenastrum & $Y=-78.803\left(\log _{10} \chi\right)+\mid 43.654$ & 0.67 \\
& Microcoleus & $Y=-93.000\left(\log _{10} \chi\right)+94.993$ & 0.93 \\
\hline
\end{tabular}

${ }^{a} \mathbf{X}$ is the concentration of the test substance.

Table 8 EC50 values ${ }^{a}$ of the trace elements and SASE for the test algae

\begin{tabular}{|c|c|c|c|}
\hline $\begin{array}{l}\text { Test } \\
\text { substance }\end{array}$ & Alga & $\log _{10} E C 50$ & $\mathrm{EC} 50^{\mathrm{b}}$ \\
\hline \multirow{3}{*}{ As } & Ankistrodesmus & $-0.59 \pm 0.17^{c}$ & 0.256 \\
\hline & Scenedesmus & $-1.32 \pm 0.17$ & 0.048 \\
\hline & Selenastrum & $1.49 \pm 0.20$ & 30.8 \\
\hline \multirow{4}{*}{$\mathrm{Cd}$} & Ankistrodesmus & $-1.7 \mid+0.12$ & 0.019 \\
\hline & Scenedesmus & $-2.30 \pm 0.32$ & 0.005 \\
\hline & Selenastrum & $-1.73 \pm 0.25$ & 0.019 \\
\hline & Microcoleus & $-1.83 \pm 0.13$ & 0.015 \\
\hline \multirow{4}{*}{$\mathrm{Hg}$} & Ankistrodesmus & $1.11 \pm 0.25$ & 0.078 \\
\hline & Scenedesmus & - $1.07 \pm 0.24$ & 0.085 \\
\hline & Selenastrum & $-1.48 \pm 0.17$ & 0.033 \\
\hline & Microcoleus & $-0.60 \pm 0.11$ & 0.253 \\
\hline \multirow{4}{*}{$\mathrm{Se}$} & Ankistrodesmus & $-1.49 \pm 0.10$ & 0.033 \\
\hline & Scenedesmus & $-0.53+0.09$ & 0.294 \\
\hline & Selenastrum & $-0.56 \pm 0.03$ & 0.277 \\
\hline & Microcoleus & $0.93 \pm 0.06$ & 8.51 \\
\hline \multirow{4}{*}{ SASE } & Ankistrodesmus & $1.05+0.18$ & 11.3 \\
\hline & Scenedesmus & $0.95 \pm 0.15$ & 8.83 \\
\hline & Selenastrum & $1.19 \pm 0.16$ & 15.4 \\
\hline & Microcoleus & $0.48 \pm 0.05$ & 3.05 \\
\hline
\end{tabular}

${ }^{\mathrm{a}} \mathrm{mg} / \mathrm{L}$ trace elements and \% SASE.

${ }^{\mathrm{b}}$ EC50 re-transformed from log scale.

'Standard error of estimate.

\section{Discussion}

Toxicity tests provide an important method of assessing the biological effects of elements in solution, and the adapted Algal Assay Procedure Bottle Test-Algal Assay Medium (AAPBT-AAM) provides a good culture medium for evaluating the effect of dissolved substances on algae. The medium is buffered to maintain $\mathrm{pH}$ near neutrality has a total dissolved solids concentration of less than $70 \mathrm{mg} / \mathrm{L}$ and when formulated without EDTA, is completely inorganic. The importance of using a test medium similar in ionic strength to the lower ionic strength of natural fresh waters is indicated in the literature. ${ }^{13}$

Chelating agents were omitted from our culture solutions because they have been shown to counteract inhibition of growth in toxicity studies. ${ }^{14}$ Awasthi \& Das ${ }^{15}$ omitted organic chelators to minimize chemical complications when investigating heavy metal toxicity to algae. Additionally, Tawarada et al. ${ }^{16}$ reported EDTA displays a strong tendency to complex with cadmium. The adjustment of the algal assay solution to $\mathrm{pH} 7.0 \pm 0.3$ with $\mathrm{NaOH}$ or $\mathrm{HCI}$ reduced the possibility of $\mathrm{pH}$-trace element interactions affecting the algal responses. Laboratory investigations indicated that small additions of $\mathrm{NaOH}$ and HCI did not significantly affect growth of the algal species. This methodology was used by Horvatić et al. ${ }^{17}$ Vigneault \& Campbell ${ }^{18}$ reported that cadmium accumulation was $\mathrm{pH}$ dependent.

The use of $\mathrm{HCl}$ to dissolve particulates formed during autoclaving of the medium reduced the possibility of occlusion, adsorption, or precipitation of the trace element being studied. ${ }^{19}$ Pyta \& RogulaKozłowska ${ }^{20}$ found that mercury accumulated in the particulate fraction of the culture medium. Martins et al. ${ }^{21}$ speculated that cadmium was occluded when calcium carbonate precipitated in his test solutions. Micronutrients were omitted in order to reduce the possibility of synergistic or antagonistic effects. Hart \& Bertram ${ }^{22}$ reported that the concentration of manganese in the medium regulated the amount of cadmium accumulated in Chlorella pyrenoidosa. Virtually no cadmium accumulation occurred in cells grown in medium containing $0.2 \mathrm{mg} / \mathrm{L}$ manganese. Wong \& Beaver $^{23}$ also omitted heavy metal micronutrients from the medium when investigating heavy metal toxicity with algal bioassays. Use of only a small quantity of sulfur in selenium assays is important because sulfur and selenium compounds have been shown to display antagonistic effects. ${ }^{24}$

To provide a viable extrapolation from the laboratory to the natural environment, we selected the dominant oxidation states of the trace elements occurring in unpolluted, natural freshwaters which are aerobic and slightly alkaline. Axenic unialgal cultures were used, when possible, for these static algal toxicity tests. Bacterial conversion of mercury ion to the organic and/or elemental form and subsequent volatilization from non-acidified media was reported by Finley \& McLaughlin. ${ }^{25}$ Microorganisms vary from species to species in their sensitivity to toxic substances, exhibit different dose-response relationships, and display different bioconcentration abilities. For this reason, considerable variance between experiments should be anticipated with a mixed inoculum because the relative species composition of the inocula would not be consistent. Unknown 
interactions could occur, making interexperimental comparisons of dose-response relationships difficult.

The use of an inoculum of uniformly low density in these investigations reduced the possibility of an algal overload. Hart \& Bertram $^{22}$ indicated that cell concentration affected the toxicity of $\mathrm{Hg}$ (II) to Chlorella pyrenoidosa. Pearson ${ }^{26}$ reported that the toxicity of mercurial compounds decreased with increasing cell concentrations. Variations in the growth phase and metabolic activity of the inoculum were reduced by inoculating the test solutions from 10- to 14-day stock cultures. Prior determination of growth curves for each alga under the test conditions established that cultures of this age were healthy and had not entered the stationary phase, although the population was increasing at a decreasing rate. The AAPBT recommends the use of 10- to 14-day cultures of Selenastrum capricornutum. A 2 week period for the algal toxicity studies was chosen for these reasons.

A standard "temperature of $24 \pm 2^{\circ} \mathrm{C}$ was used because temperaturetrace metal interactions have been shown to affect algal responses. ${ }^{27}$ The static toxicity tests employed in this investigation may have tended to underestimate the toxicity of low-level treatments because the low-level concentrations of the potential metal pollutants could have been further reduced during the tests through bioaccumulation and possibly volatilization in the case of $\mathrm{Hg}$ (II). ${ }^{28}$ If the tests had been conducted in a continuous-flow algal system, then the first significant inhibition levels of As (V), Cd (II), Hg (II), Se (VI), and SASE might have been reduced. The ECS0 values, however, are much less affected by this depletion.

Little information is available concerning the toxicity of arsenic to freshwater algae. The algistafic-algicidal value reported for Chlorella vulgaris of $0.06 \mathrm{mg} / \mathrm{L} \mathrm{As}(\mathrm{V})$ by Jiang et al. ${ }^{29}$ is well below the algistatic-algicidal value of $5.0 \mathrm{mg} / \mathrm{L} \mathrm{As}(\mathrm{V})$ for Ankistrodesmus, the alga with the lowest algistatic-algicidal value. Mekhalfi et al. ${ }^{30}$ reported no detrimental effects to Asterionella formosa when this freshwater diatom was exposed to $0.16 \mathrm{mg} / \mathrm{L} \mathrm{As}(\mathrm{V})$. Additionally, the EC50 values $(0.048$ to $>100 \mathrm{mg} / \mathrm{L})$ and the algistatic-algicidal values ( 5 to $>100 \mathrm{mg} / \mathrm{L}$ ) displayed a large degree of variation from alga to alga. The blue-green alga Microcoleus was much more tolerant of $\mathrm{As}(\mathrm{V})$ than the green algae investigated. This could be due in part to differences in the assay media, the fact that the Microcoleus was not axenic, or possibly because Microcoleus is a prokaryotic organism while the other organisms tested were eukaryotes.

This investigation confirms reports that cadmium is extremely toxic to freshwater algae. Cadmium concentrations of 0.13 and $0.08 \mathrm{mg} / \mathrm{L}$ for Selenastrum capricornutum, $0.14 \mathrm{mg} / \mathrm{L}$ for Chlorella vulgaris, and $>0.01 \mathrm{mg} / \mathrm{L}$ for Asterionella formosa were reported as algistatic-algicidal, ${ }^{31}$ respectively. In this investigation, algistaticalgicidal values between $0.1-0.2,0.01-0.05,0.2-0.3$ and $0.1-0.3 \mathrm{mg} / \mathrm{L}$ Cd(II) were indicated for Ankistrodesmus, Scenedesmus, Selenastrum, and Microcoleus, respectively.

Hart \& Bertram ${ }^{22}$ reported that a Cd(II) concentration of $0.25 \mathrm{mg} / \mathrm{L}$ as $\mathrm{Cd}\left(\mathrm{CH}_{3} \mathrm{CO}_{2}\right)_{2} \cdot 2 \mathrm{H}_{2} \mathrm{O}$ inhibited the growth rate of Chlorella pyrenoidosa cultures in the logarithmic growth phase. Cheng et al. ${ }^{31}$ found Chlorella vulgaris to be more sensitive and reported an abrupt inhibition of growth by concentrations of cadmium above $0.05 \mathrm{mg} / \mathrm{L}$. Liu et al. ${ }^{32}$ observed that Cd(II) concentrations as low as $0.0061 \mathrm{mg} / \mathrm{L}$ $\mathrm{CdCl}_{2}$ had a significant inhibitory effect on Scenedesmus quadracauda and that $0.061 \mathrm{mg} / \mathrm{L}$ severely inhibited growth.

The EC50 value of $0.06 \mathrm{mg} / \mathrm{L} \mathrm{Cd}(\mathrm{II})$ as $\mathrm{CdCl}_{2}$ reported by
Oyamada et al. ${ }^{33}$ for Chlorella vulgaris is slightly higher than the EC50 values of $0.019,0.005,0.019$, and $0.015 \mathrm{mg} / \mathrm{L} \mathrm{Cd(II)} \mathrm{found}$ in this investigation for Ankistrodesmus, Scenedesmus, Selenastrum, and Microcoleus, respectively. No marked difference in sensitivity to $\mathrm{Cd}(\mathrm{II})$ was noticed between blue-green and green algae.

The algistatic-algicidal values of $0.1-0.4 \mathrm{mg} / \mathrm{L} \mathrm{Hg}(\mathrm{II})$ for the green algae and approximately $1.0 \mathrm{mg} / \mathrm{L} \mathrm{Hg}$ (II) for Microcoleus compare favorably with values reported in the literature. Mercuric chloride concentrations of $2.0 \mathrm{mg} / \mathrm{L}$ for Chlamydomonas reinhardi $\mathrm{y}^{-1} 0.037 \mathrm{mg} / \mathrm{L}$ for Chlorella vulgaris, and $1.0 \mathrm{mg} / \mathrm{L}$ for Chlorella pyrenoidosa were reported as algistatic-algicidal by Shen. ${ }^{34}$ Tompkins \& Blinn ${ }^{35}$ reported algistatic-algicidal responses at $0.1 \mathrm{mg} / \mathrm{L}$ and $0.5 \mathrm{mg} / \mathrm{L} \mathrm{Hg}(\mathrm{II})$ as $\mathrm{HgCI}_{2}$ for Fragilaria crotonensis and Asterionella formosa, respectively, and $\mathrm{Oh} \& \mathrm{Koh}^{36}$ reported an algistatic-algicidal response at $0.2 \mathrm{mg} / \mathrm{L} \mathrm{Hg}(\mathrm{II})$ as inorganic mercury for Chlorella vulgaris. Tezuka \& Takasaki ${ }^{37}$ reported less than $25 \mu \mathrm{g} / \mathrm{L} \mathrm{Hg}(\mathrm{II})$ as phenylmercuric acetate resulted in an algicidal-algistatic response in Phaeodactylum tricornutum, Chlorella sp. and Chlamydomonas sp. The EC50 values of $0.078,0.085,0.033$, and $0.253 \mathrm{mg} / \mathrm{L} \mathrm{Hg}(\mathrm{II})$ for Ankistrodesmus, Scenedesmus, Selenastrum and Microcoleus respectively, are smaller than the $1.03 \mathrm{mg} / \mathrm{L} \mathrm{Hg}(\mathrm{II})$ as $\mathrm{HgCI}_{2}$ reported by Patil $^{38}$ for Chlorella vulgaris. The blue-green alga Microcoleus appears to be somewhat less sensitive to $\mathrm{Hg}(\mathrm{II})$, but this could be due to differences in test media or to the fact that the Microcoleus was not axenic.

Little information is available concerning the toxicity of selenate to freshwater algae. Tomioka et al. ${ }^{39}$ reported an algistatic-algicidai response of the blue-green alga Anacystis nidulans at $20 \mathrm{mg} / \mathrm{L} \mathrm{Se}(\mathrm{VI})$ as $\mathrm{Na}_{2} \mathrm{SeO}_{4}$. The algistatic-algicidal levels in this investigation ranged from $1.7 \mathrm{mg} / \mathrm{L} \mathrm{Se}(\mathrm{VI})$ for Selenastrum to $>50 \mathrm{mg} / \mathrm{L}$ for Microcoleus. No response values for green algae exposed to $\mathrm{Se}(\mathrm{VI})$ were found in the literature. Although it appears that green algae are more sensitive to $\mathrm{Se}(\mathrm{VI})$ than are blue-green algae, the antagonistic response between sulfur and selenium in the different media complicates this relationship. Our EC50 values, which ranged from 0.033-8.511 mg/L $\mathrm{Se}(\mathrm{VI})$, are not directly comparable to any values in the literature.

Sun et al. ${ }^{40}$ reported an algistatic-algicidal response of Chlorella vulgaris to $12 \mathrm{mg} / \mathrm{L} \mathrm{Se}(\mathrm{IV})$ as $\mathrm{Na}_{2} \mathrm{SeO}_{3}$. Kumar \& Prakash ${ }^{41}$ reported LD50 values for Anabaena variabilis and Anacystis nidulans at $13 \mathrm{mg} / \mathrm{L}$ and $31 \mathrm{mg} / \mathrm{L} \mathrm{Se}(\mathrm{IV})$ as $\mathrm{Na}_{2} \mathrm{SeO}_{3}$, respectively, and at $18 \mathrm{mg} / \mathrm{L}$ and $42 \mathrm{mg} / \mathrm{L} \mathrm{Se}(\mathrm{VI})$ as $\mathrm{Na}_{2} \mathrm{SeO}_{4}$, respectively. The response values obtained from the literature for Se(IV) are not, however, directly comparable to $\mathrm{Se}(\mathrm{VI})$ response values.

The demonstrated interspecies variation in sensitivity to the test substances in this study indicates that more than one algal species should be utilized when assessing the potential impact of toxic trace elements on an ecosystem. The use of a standard species such as Selenastrum capricornutum for interlaboratory comparisons is recommended for purposes of quality control. However, dependence on a single species can provide erroneous results concerning the potential toxicity of a toxic element in a given ecosystem. The highly toxic nature of potential pollutants from coal-fired generating plants to indigenous algae emphasizes the need for minimizing stack effluent pollutants and detaining scrubber ash slurry for proper disposal. Efforts should be made to maintain trace elements within concentration ranges which are compatible with the natural functioning of the associated aquatic ecosystems. 


\section{Acknowledgements}

The author is thankful to Prof. Loai Aljerf, the editor in the Biodiversity International Journal for his scientific assistance and his appreciated backup which eased reaching this paper to its final edition.

\section{Conflict of interest}

Author declares that no competing interests exist.

\section{References}

1. Spitz N, Saveliev R, Perelman M, et al. Firing a sub-bituminous coal in pulverized coal boilers configured for bituminous coals. Fuel. 2008;87(8-9):1534-1542.

2. Yinghui L, Chuguang Z, Quanhai W. Speciation of most volatile toxic trace elements during coal combustion. AsiaPacific Journal of Chemical Engineering. 2008;11(3-4):381-394.

3. Qi LQ, Zhang YJ. Investigation on the characteristic of fly ash in electrostatic precipitators. Advanced Materials Research. 2012;518:869-872.

4. Mahlaba JS, Kearsley EP, Kruger RA. Physical, chemical and mineralogical characterisation of hydraulically disposed fine coal ashfrom SASOL Synfuels. Fuel. 2011;90(7):2491-2500.

5. Mwakabona HT. The growing global demand for element gallium: electrical and electronic waste and coal fly ash as alternative sources for its sustainable supply. International Journal of Science and Research. 2017;6(1):1287-1293.

6. Jiru M. Coal-fired power plants and their impact on ecosystems health. Physical Science International Journal. 2017;16(4):1-7.

7. Hao Y, Li Q, Pan Y, et al. Heavy metals distribution characteristic of FGD gypsum samples from Shanxi province 12 coalfired power plants and its potential environmental impacts. Fuel. 2017;209:238-245

8. Zamri SNAM, Sulaiman MA, Ismail S, et al. Bacto-Agar and commercial agar as binder for porous zinc anode. Solid State Phenomena. 2017;264:136-139.

9. Wang P, Li Z, Ismail S, et al. Optimization of microalgal bead preparation with Scenedesmus obliquus for both nutrientremoval and lipid production. Ecological Engineering. 2016;92:236-242.

10. Nojiri H, Okoshi M. Crack suppression of silica glass formed by zoned F2laser-induced photochemical surface modification of hard silicone thin film coating on polycarbonate. Japanese Journal of Applied Physics. 2016;55(12):122701.

11. Hai R, Feng H, Wang W. Adsorption of mercury(II) by beer yeast immobilized in chitosan/silicone leg. Asian Journal of Chemistry. 2013;25(12):6528-6530.

12. Lee DK, Cho YH, Lee JW, et al. Wettability of microstructured Pyrex glass with hydrophobic and hydrophilic properties. Surface and Coatings Technology. 2017;319:213-218.

13. Jackson G, Seymour LF. Formation constants at high ionic strengthII. The ionic strength correction of formation constants using a simplified pitzer equation. Talanta. 1995;42(1):9-16.

14. Eklund B. Review of the use of Ceramium tenuicorne growth inhibition test for testing toxicity of substances, effluents, products sediment and soil. Estuarine, Coastal and Shelf Science. 2017;195:88-97.
15. Awasthi M, Das DN. Heavy metal toxicity on nitrate reductase activity of free and immobilized algal cells. International Journal on Algae. 2004;6(2):151-157.

16. Tawarada K, Sasaki K, Ohmura N, et al. Preparation of anti-cadmiumEDTA complex monoclonal antibody and its binding specificity. Bunseki Kagaku. 2003;52(8):583-587.

17. Horvatić J, Palijan G, Lukavský J. Algal responses to nutrient additions in water of Nature Park Kopački Rit (Croatia) by Miniaturized Algal Growth Bioassay. Algological Studies. 2003;110(1):117-126.

18. Vigneault B, Campbell PGC. Uptake of cadmium by freshwater green algae: effects of $\mathrm{pH}$ and aquatic humic substances. Journal of Phycology. 2005;41(1):55-61.

19. Nouchpramool S, Sumitra T, Leenanuphunt V. Characterization of airborne particulates in bangkok urban area by neutron activation analysis. Biological Trace Element Research. 1999;71(1):181-187.

20. Pyta H, Rogula-Kozłowska W. Determination of mercury in sizesegregated ambient particulate matter using CVAAS. Microchemical Journal. 2016;124:76-81.

21. Martins RJE, Pardo R, Boaventura RAR. Cadmium(II) and zinc(II) adsorption by the aquatic moss Fontinalis antipyretica: effect of temperature, $\mathrm{pH}$ and water hardness. Water Research. 2004;38(3):693-699.

22. Hart BA, Bertram PE. A cadmium-binding protein in a cadmium tolerant strain of Chlorella pyrenoidosa. Environmental and Experimental Botany. 1980;20(2):175-180.

23. Wong SL, Beaver JL. Algal bioassays to determine toxicity of metal mixtures. Hydrobiologia. 1980;74(3):199208.

24. Müller R, Heinze J. Stabilization of oxidized sulfur and selenium centers in organic chalcogens by three-electron sulfur-sulfur, selenium-selenium, and sulfurselenium bonds. A theoretical study using the semiempirical PM3 method. Phosphorus, Sulfur, and Silicon and the Related Elements. 1998;141(1):111-134.

25. Finley HE, McLaughlin D. Cultivation of the Peritrich Telotrochidium henneguyi in axenic and non-axenic media. A theoretical study using the semiempirical PM3 method. The Journal of Protozoology. 1965;12(1):41-47.

26. Pearson TW. Effect of mercurial perturbation on avian uterine calcium transport. Cell Calcium. 1981;2(2):137-144.

27. Rijstenbil JW, Gerringa Interactions of algal ligands, metal complexation and availability, and cell responses of the diatom Ditylum brightwellii with a gradual increase in copper. Aquatic Toxicology. 2002;56(2):115-131.

28. Rainbow PS. Trace metal bioaccumulation: Models, metabolic availability and toxicity. Environment International. 2007;33(4):576-582.

29. Jiang $\mathrm{X}, \mathrm{Ren} \mathrm{C}, \mathrm{Hu} \mathrm{C}$, et al. Isolation and algicidal characterization of Bowmanella denitrificans S088 against Chlorella vulgaris. World Journal of Microbiology and Biotechnology. 2013;30(2):621-629.

30. MekhalfiM,AmaraS, RobertS, etal.Effectofenvironmental conditions on various enzyme activities and triacylglycerol contents in cultures of the freshwater diatom, Asterionella formosa (Bacillariophyceae) Biochimie. 2014;101:21-30. 
31. Cheng J, Qiu H, Chang Z, et al. The effect of cadmium on the growth and antioxidant response for freshwater algae Chlorella vulgaris. Springerplus. 2016;5(1):1290.

32. Liu A, Tian D, Xiang Y, et al. Biochar improved growth of an important medicinal plant (Salvia miltiorrhiza Bunge) and inhibited its cadmium uptake. Journal of Plant Biology \& Soil Health. 2016;3(2):6.

33. Oyamada N, Takahashi G, Ishizaki M. Methylation of inorganic selenium compounds by feshwater green Algae, Ankistrodesmus sp., Chlorella vulgaris and Selenastrum sp. Eisei kagaku. 1991;37(2):83-88.

34. Shen S. Genetic diversity analysis with ISSR PCR on green algae Chlorella vulgaris and Chlorella pyrenoidosa. Chinese Journal of Oceanology and Limnology 2008;26(4):380-384.

35. Tompkins T, Blinn DW. The effect of mercury on the growth rate of Fragilaria crotonensis kitton and Asterionella formosa Hass. Hydrobiologia. 1976;49(2):111-116.

36. Oh S, Koh SC. Chlorophyll a fluorescence response to mercury stress in the freshwater Microalga Chlorella vulgaris. Journal of Environmental Science International. 2013;22(6):705-715.
37. Tezuka T, Takasaki Y. Biodegradation of phenylmercuric acetate by organomercury-resistant Penicillium sp. MR-2. Agricultural and Biological Chemistry. 2013;52(12):3183-3185.

38. Patil HS. The role of Ankistrodesmus falcatus and Scenedesmus quadricauda in sewage purification. Bioresource Technology. 1991;37(2):121-126.

39. Tomioka N, Shinozaki K, Sugiura M. Molecular cloning and characterization of ribosomal RNA genes from a bluegreen alga, Anacystis nidulans. MGG Molecular \& General Genetics. 1981;184(3):359-363.

40. Sun X, Zhong Y, Huang Z, et al. Selenium accumulation in unicellular green Alga Chlorella vulgaris and its effects on antioxidant enzymes and content of photosynthetic pigments. PLoS ONE. 2014;9(11):e112270.

41. Kumar HD, Prakash G. Toxicity of selenium to the Blue-green Algae, Anacystis nidulans and Anabaena variabilis. Annals of Botany. 1971;35(3):697-705. 